\title{
Stomach contents of the kuruma shrimp Marsupenaeus japonicus from the western Mediterranean Egyptian coast
}

\author{
Nesreen K. Ibrahim ${ }^{1} *$, Mohamed H. Yassien ${ }^{2}$ and Sh. A. Seif ${ }^{1}$ \\ 1- Marine Science Department, Faculty of Science, Suez Canal University, Ismailia, Egypt. \\ 2- National Institute of Oceanography and Fisheries, Suez branch, Egypt. \\ *Email: Kadry1339@yahoo.com
}

\begin{abstract}
:
The stomach content of 1000 and 1293 specimens from males and females respectively of Marsupenaeus japonicus, inhabiting the western Mediterranean Egyptian coast, were studied monthly from May 2015 to April 2016. The aim of this study was to identify the diet items of $M$. japonicus based on the analysis of the stomach contents. The stomach analysis was carried out by using the frequency of occurrence $(\mathrm{O} \%)$ and numerical methods $(\mathrm{N} \%)$. The kuruma shrimp $M$. japonocus is omnivorous, but with an important carnivorous component, mainly on crustacean and fish remains. Represented data of this study indicated that M. japonicus has not food preference between sexes. Stomach contents of adult and juvenile specimens were similar. The quantitative analysis and seasonally variations in the feeding intensity was quite high during the summer, autumn and winter.
\end{abstract}

Key words: Stomach content, kuruma shrimps, Marsupenaeus japonocus, western Mediterranean of the Egyptian coast.

\section{INTRODUCTION}

Prawns are one of the most economically important marine living resources in the western Mediterranean Egyptian coast. They are considered as an important source of food as well as a source of national income due to their high prices and strong demand on the local and international markets. Marsupenaeus japonicus, is known as the kuruma shrimp, kuruma prawn, or Japanese tiger prawn. It occurs naturally in bays and seas of the Indo-West Pacific, but has also reached the Mediterranean Sea as a Lessepsian migrant. It is nocturnal, one of the largest species of prawns, and is accordingly one of the most economically important species in the family Penaeidae. Despite the great importance of prawn as a major economic fishery in western Mediterranean Egyptian coast, little is known about its biology (Yassien, 1992, 2005; Yassien et al., 1993).

There is no available information on the diet composition of penaeid prawn from the Egyptian coast, except that given by Al-Kholy and El-Hawary (1970) in the Red Sea. AbdelRazek (1974) studied the food and feeding habits of $P$. japonicas from eastern Mediterranean, while Ishaket al. (1980) investigated the types of food of P. kerathurus transplanted into Lake Quarun. Yassien (2004) studied the stomach contents of three penaeid prawns namely, Penaeus latisulcatus, P. semisulcatus and P. japonicus from the Gulf of Suez.

The study of food and feeding habits of prawn is essential for understanding its ecology and behavior. Also, the feeding habits have focused on investigated the role of prawns in the benthic communities and examined their impacts upon the structure and function of macrofauna. In addition studying the food and feeding of prawn helps in the potential aquaculture of this group of invertebrates. 


\section{Nesreen K. Ibrahim et al.}

The present study embodies the results of the food content analysis of the bottom penaeid prawns Marsupenaeus japonicus from the western Mediterranean Egyptian coast fishing grounds as well as the variations of their diets according to season and size classes.

\section{MATERIALS AND METHODS}

The western Egyptian Mediterranean coast includes the area between Alexandria and ElSalum on the Libyan border (Figure 1).

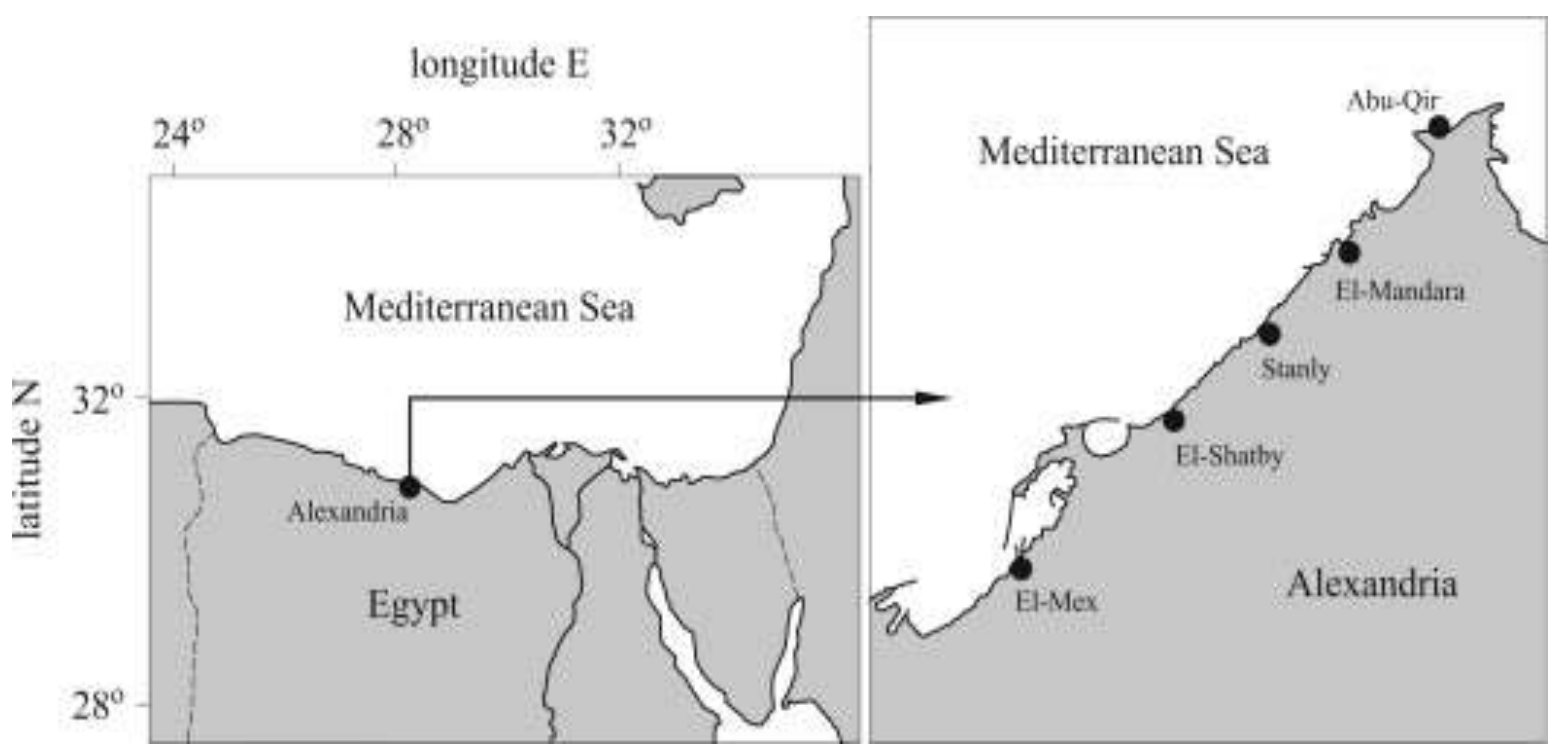

Fig.1: Map of the western Mediterranean Egyptian coast

Samples were collected monthly from May 2015 to April 2016 from artisanal fishing that use trawling nets.The specimens were immediately placed into plastic tanks containing crushedice. At the lab., both sexes were separated. Carapace length (CL) was measured (using Vernier calliper) by the linear distance from the tip of the rostrum to the end of the carapace to describe the relationship between biometric and stomach content.The effect of prawn size on diet was examined by comparing diet of prawns in $2 \mathrm{~cm}$ CL size classes for both males and females. Specimens of both sexes were dissected; stomach contents were removed in a counting cell. Items were separated, examined under a stereoscopic microscope and identified to the smaller taxonomic unit as possible. The quantitative analysis of food items was performed using two methods: the numerical frequency $(\mathrm{N} \%)$ and the relative frequency of occurrence $(\mathrm{O} \%)$ (Williams, 1981; Wear\& Haddon, 1987).The relative contribution of each food item (i) in the speciemns' stomach was estimated by the numerical method (N\%) which was evaluated by the percentage of each food item in relation to the total number of all food items (Hyslop, 1980). The frequency of occurrence was estimated according to Hyslop (1980). The percentage in the diet for each taxon was calculated according to the following equation: $\left(f_{i} / \epsilon f\right) \times 100$

Where $f i$ is the frequency of occurrence of certain food item and $f f$ is the frequency of occurrence of all food items. 


\section{Stomach contents of the kuruma shrimp Marsupenaeus japonicus from the western Mediterranean Egyptian coast}

Degree of fullness was visually evaluated and categorized to four classes according to Barutot et al. (2011) as follows: class I empty (less than 25\%), class II moderately empty ( $<50 \%$ and $>25 \%$ full), class III moderately full $(<75 \%$ and $>50 \%$ full) and class IV very full $(>75 \%$ to $100 \%$ full). The differences between frequencies of occurrence of the diet items for both sexes were analyzed by using Chi-square test $(\chi 2)$ (Zar, 1996). One way ANOVA was used to evaluate the variations between stomach fullness and sex, season and size.

\section{RESULTS}

A total of 2293 specimens of Marsupenaeus japonicus were analyzed, 1000 males and 1293 females. The results indicated that crustaceans were the main prey item in the diet of $M$. japonicus followed by broken shells, fish remains, algal fragments, foraminifera, diatoms and sand grains. Items that could not be identified were classified as undetermined matter (UM). The overall numerical percentage $(\mathrm{N} \%)$ and percentage of frequency of occurrence $(\mathrm{O} \%)$ of different food items show that remains of large crustaceans, broken shells and fish remains constituted the main food items. They accounted for about $94.5 \%$ and $92.3 \%(\mathrm{~N} \%), 89.5 \%$ and $85.8 \%(\mathrm{O} \%)$ of the diet composition for both males and females, respectively (Table 1). $\chi^{2}$ test showed no significant differences between diet composition of males and females $(\mathrm{P}>0.05)$.

Table (1). Numerical percentage $(\mathrm{N} \%)$ and percentage occurrence $(0 \%)$ of the different food items in the stomachs of Marsupenaeus japonicus collected from the western Mediterranean Egyptian coast during the period from May 2015 till April 2016.

\begin{tabular}{|c|c|c|c|c|}
\hline & \multicolumn{2}{|c|}{ N\% } & \multicolumn{2}{c|}{ O\% } \\
\hline Food items & Males & Females & Males & Females \\
\hline Crustaceans & 76.7 & 79.6 & 74.1 & 68.1 \\
\hline Broken Shells & 12.1 & 8.7 & 11.1 & 12.5 \\
\hline Fish remains & 5.7 & 4.0 & 4.3 & 5.2 \\
\hline Algal fragments & - & - & 3.6 & 4.1 \\
\hline Foraminifera & 1.6 & 2.5 & 1.4 & 1.9 \\
\hline Diatoms & 1.1 & 3.0 & 1.8 & 3.0 \\
\hline Sand grains & - & - & 1.8 & 2.6 \\
\hline UM & 2.9 & 2.3 & 1.9 & 2.7 \\
\hline
\end{tabular}

Data expressed as percentage (\%), ( - ) No food item occurred, (UM) unidentified material

Carapace length ranged from 1.0 to $9.9 \mathrm{~cm}$ for females and from 2.0 to $9.9 \mathrm{~cm}$ for males. It was classified into 8 groups for males and 9 groups for females with $1.0 \mathrm{~cm}$ interval (Tables 2 $\& 3)$. The ANOVA test showed no significant differences $(\mathrm{P}<0.05)$ in the frequency of diet items between different size classes in males and females of studied species. 
Nesreen K. Ibrahim et al.

Table (2).Numerical percentage $(\mathrm{N} \%)$ and percentage occurrence $(\mathrm{O} \%)$ of the different food items in the stomachs of females Marsupenaeus japonicus collected from the Mediterranean Egyptian coast during the period from May 2015 till April 2016.

\begin{tabular}{|c|c|c|c|c|c|c|c|c|c|c|c|c|c|c|c|c|c|c|}
\hline \multirow[b]{3}{*}{ Food items } & \multicolumn{18}{|c|}{ Carapace length groups (cm) } \\
\hline & \multicolumn{2}{|c|}{$1.0 \cdot 1.9$} & \multicolumn{2}{|c|}{$2.0-2.9$} & \multicolumn{2}{|c|}{$3.0-3.9$} & \multicolumn{2}{|c|}{$4.0-4.9$} & \multicolumn{2}{|c|}{$5.0-5.9$} & \multicolumn{2}{|c|}{$6.0-6.9$} & \multicolumn{2}{|c|}{$7.0 \cdot 7.9$} & \multicolumn{2}{|c|}{$8.0 \cdot 8.9$} & \multicolumn{2}{|c|}{$9.0-9.9$} \\
\hline & $\mathrm{N} \%$ & $0 \%$ & $\mathrm{~N} \%$ & $0 \%$ & $\mathrm{~N} \%$ & $0 \%$ & $\mathrm{~N} \%$ & $0 \%$ & $\mathrm{~N} \%$ & $0 \%$ & $\mathrm{~N} \%$ & $0 \%$ & $\mathrm{~N} \%$ & $0 \%$ & $\mathrm{~N} \%$ & $0 \%$ & $\mathrm{~N} \%$ & $0 \%$ \\
\hline Crustacea & 80.1 & 66.7 & 81.2 & 67.4 & 82.2 & 68.3 & 82.3 & 60.2 & 82.3 & 62.3 & 88.1 & 67.7 & 82.1 & 64.7 & 88.1 & 61.6 & 81.2 & 63.3 \\
\hline Broken shells & 8.3 & 12.2 & 8.4 & 13.5 & 8.7 & 13.3 & 7.7 & 11.1 & 8.8 & 11.8 & 9.3 & 14.2 & 8.8 & 14.2 & 8.9 & 13.3 & 8.8 & 11.1 \\
\hline Fish remains & 4.3 & 5.2 & 4.6 & 4.9 & 4.4 & 5.4 & 3.8 & 5.4 & 4.4 & 4.7 & 3.7 & 4.9 & 4.4 & 5.1 & 4.8 & 5.5 & 4.5 & 5.5 \\
\hline Algal fragments & - & 3.9 & - & 4.2 & - & 3.7 & - & 3.3 & - & 2.9 & - & 3.8 & - & 3.9 & - & 4.1 & - & 3.8 \\
\hline Foraminifera & 2.7 & 1.9 & 2.8 & 2.1 & 2.9 & 1.8 & 3.6 & 1.8 & 2.8 & 1.9 & 2.9 & 1.8 & 2.3 & 1.8 & 2.6 & 2.1 & 2.4 & 1.8 \\
\hline Diatoms & - & 2.8 & - & 3.9 & - & 2.4 & - & 2.7 & - & 2.8 & - & 2.3 & - & 2.7 & - & 2.7 & - & 2.7 \\
\hline Sand grains & - & 2.6 & - & 3.2 & - & 2.7 & - & 2.7 & 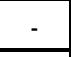 & 2.5 & - & 2.7 & - & 2.4 & - & 2.7 & - & 2.4 \\
\hline $\mathrm{UM}$ & 2.4 & 2.7 & 2.5 & 3.3 & 2.5 & 2.5 & 3.6 & 2.9 & 2.5 & 2.3 & 3.4 & 2.9 & 2.9 & 2.3 & 2.6 & 2.3 & 2.9 & 2.9 \\
\hline
\end{tabular}

Data expressed as percentage (\%), ( - ) No food item occurred

Table (3).Numerical percentage $(\mathrm{N} \%)$ and percentage occurrence $(\mathrm{O} \%)$ of the different food items in the stomachs of males Marsupenaeus japonicus collected from the Mediterranean Egyptian coast during the period from May 2015 till April 2016.

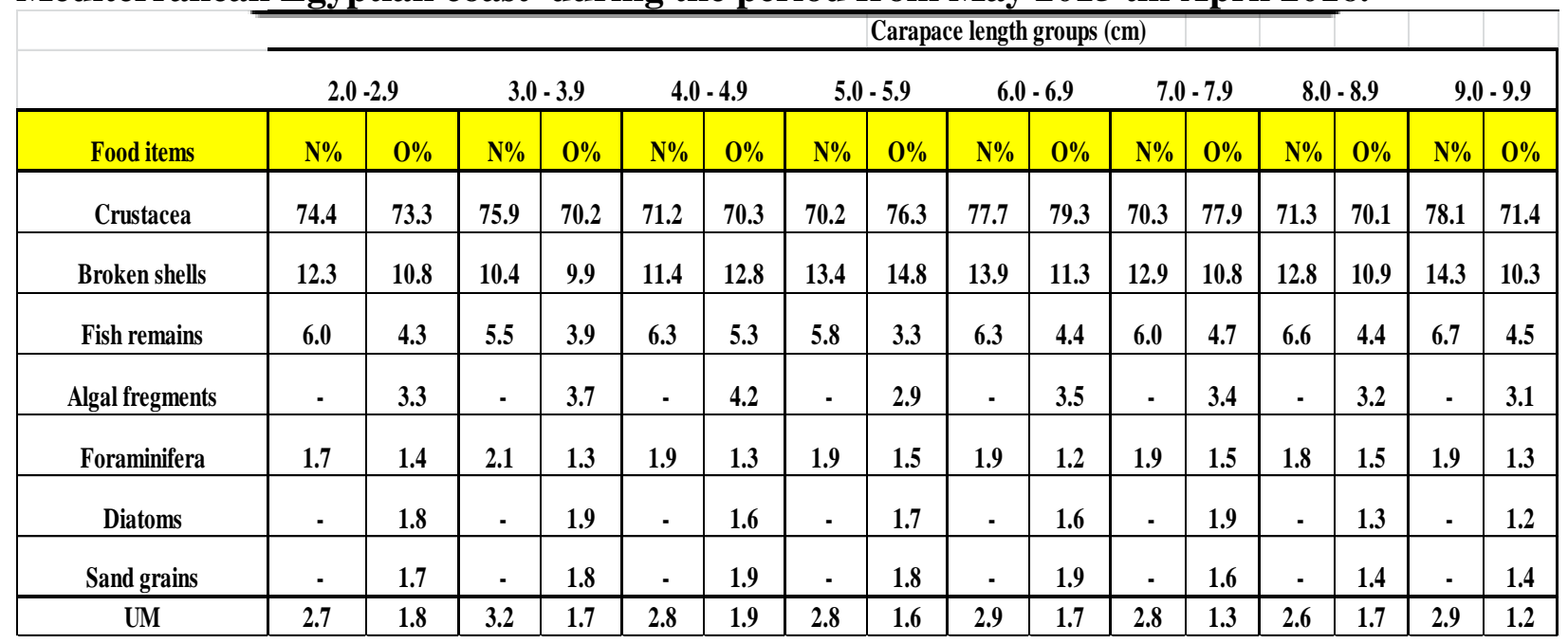

According to the degree of fullness, it was noticed that the majority of the stomachs were very full $(38.6 \%$ and $34.8 \%)$ for males and females, respectively, whereas empty stomachs were represented only $16.6 \%$ of all analyzed male stomachs and $12.2 \%$ for female ones (Table 4 ). 
Stomach contents of the kuruma shrimp Marsupenaeus japonicus from the western Mediterranean Egyptian coast

Table (4). Degree of fullness of the stomachs of Marsupenaeus japonicas collected from the western Mediterranean Egyptian coast during the period from May 2015 till April 2016.

Male fullness

\begin{tabular}{c|cc|cc|cc|cc|}
\hline $\mathrm{N}$ & I & $\%$ & II & $\%$ & III & $\%$ & IV & $\%$ \\
1000 & $\mathbf{1 6 6}$ & 16.6 & $\mathbf{1 1 9}$ & 11.9 & $\mathbf{3 2 9}$ & 32.9 & $\mathbf{3 8 6}$ & 38.6 \\
\hline
\end{tabular}

Female fullness

\begin{tabular}{c|cc|cc|cc|cc|}
\hline $\mathrm{N}$ & I & $\%$ & II & $\%$ & III & $\%$ & IV & $\%$ \\
1293 & $\mathbf{1 5 7}$ & 12.2 & $\mathbf{4 0 1}$ & 31 & $\mathbf{2 8 5}$ & 22 & $\mathbf{4 5 0}$ & 34.8 \\
\hline
\end{tabular}

Also, the ANOVA test was used to determine seasonal effects on the frequency of different food items (Tables5\& 6) and revealed significant difference $(\mathrm{P}>0.05)$. The quantitative analysis and seasonal variations in the feeding intensity of $M$. japonocus, showed considerable seasonal variations. In males, the feeding activities were slightly high during summer (58.3\%), autumn $(90.0 \%)$ and the maximum was in winter $(94.2 \%)$ (Table 5). In females there was a high rate of feeding intensity recorded in autumn $(59.0 \%)$ reaching its maximum rate in winter (79.6\%) (Table 6).

Table (5). Seasonal variations in the intensity of feeding of females Marsupenaeusjaponicuscollected from the western Mediterranean Egyptian coast during the period from May 2015 till April 2016.

\begin{tabular}{|c|c|c|c|c|c|}
\hline & \multicolumn{5}{|c|}{ The degree of females stomach fullness $\%$} \\
\hline Seasons & Number of specimens & I & II & III & IV \\
\hline Spring & 286 & 45.9 & 22.6 & 16.0 & 15.5 \\
\hline Summer & 436 & 26.1 & 29.4 & 23.8 & 20.7 \\
\hline Autumn & 204 & 3.4 & 37.6 & 22.0 & 37.0 \\
\hline Winter & 367 & 1.4 & 19.0 & 11.9 & 65.6 \\
\hline
\end{tabular}

\section{Data expressed as percentage}

Table (6). Seasonal variations in the intensity of feeding of male Marsupenaeus japonicas collected from the western Mediterranean Egyptian coast during the period from May 2015 till April 2016.

\begin{tabular}{|c|c|c|c|c|c|}
\hline & \multicolumn{5}{|c|}{ The degree males stomach fullness \% } \\
\cline { 1 - 5 } Seasons & Number of specimens & I & II & III & IV \\
\hline Spring & 166 & 45.3 & 28.8 & 14.9 & $\mathbf{1 1 . 0}$ \\
\hline Summer & 279 & 25.8 & $\mathbf{1 6 . 0}$ & $\mathbf{3 6 . 2}$ & $\mathbf{2 2 . 1}$ \\
\hline Autumn & 335 & 3.4 & 6.6 & 45.7 & 44.3 \\
\hline Winter & 220 & 3.7 & 2.2 & $\mathbf{2 2 . 8}$ & $\mathbf{7 1 . 8}$ \\
\hline
\end{tabular}




\section{Nesreen K. Ibrahim et al.}

\section{Data expressed as percentage}

\section{DISCUSSION}

The present study showed that kuruma shrimp Marsupenaeus japonicus is omnivorous, but with an important carnivorous items mainly on crustacean. This result is relatively similar to that reported by Al-Kholy and El-Hawary (1970),Abdel-Razek $(1974 ; 1985 ; 1988)$ and Yassien (2005) who studied the stomach contents of three penaeid shrimps from the Gulf of Suez. Fragmented hard parts were usually recorded in the stomach of both sexes with different sizes. Lagardère (1972) also reported this result and clarifying that the shrimp grind their food very well and ingest the small fragments which made the identification of food items at higher taxonomic level more difficult. The sand ingestion by $M$. japonicas probably occurs to help in the food breaking in response to the absence of gastric mill or teeth in the stomach. The presence of sand and other sediments in the stomach of Decapoda crustaceans has been noticed by many authors, especially by accidental ingestion with preys (Abayomiet al., 2011; Lima et al., 2014). It was obvious from high frequency of crustacean remains and shells that the studied species fed mainly on benthic form preys (crustacean). On the other hand, Bello and Pipitone (2002) and Rezende et al. (2014) found that the deep sea shrimp Aristeomorpha foliacea and Aristaeopsis edwardsiana mainly fed on pelagic forms which indicate that these deep sea shrimps are effective predators. There was no much difference in the food composition of males and females of M. japonicus, this was in full agreement with Yassein (2004).

There was no significant relationship between diet compositions of the target species and body size. This means that there was no food selectivity in large and small individuals. In contrast, Rezende et al. (2014) revealed that the deep sea shrimp Aristaeopsis edwardsiana undergoes changes in the diet composition with increasing its body size. Large individuals fed on highly mobile preys whereas small ones consumed mainly benthic preys of low mobility (Kapiris et al., 2010).

Monthly variations have evident influence on the diet composition of the studied species; this is possibly related to the high abundance of the prey populations in the environment in a special season. However, several studies have shown the responsibility of season on changes in frequency of diet composition due to biological processes such as gonad development and reproduction (Kapiriset al., 2010 ; Nouar et al., 2011.

\section{REFERENCES}

Abayomi, A.; Jimoh, E.; Clarke, O.; Olusegun, O. W. and Haleemah, B.A. (2011). Food and feeding habits of the African river prawn (Macrobrachium vollenhovenii, Herklots, 1857) in Epe Lagoon, southwest Nigeria. Int. J. Fish. Aquacult., 3: 10-15.

Abdel-Razek, F.A. (1974). Biological studies on some migrating species of the Penaeidae fromthe Mediterranean and Delta Lakesof Egypt. M.Sc.thesis, Faculty of Science, Alexandria University, $283 \mathrm{pp}$.

Abdel-Razek, F.A. (1985). Contribution to the biology of penaeid prawns of the Mediterranean coast of Egypt. Maturation and spawning, J. Egypt.Veterinary,45:2, 17-28.

Abdel-Razek, F.A.(1988). Notes on the bionomic of the penaeid prawns in Lake Borolos, Egypt. Pvoc. Zoological Society. 15.

Al-Kholy, A.A. and El-Hawary, M.M. (1970). Some penaeids of the Red Sea. Bull. Inst. Oceanogr. and Fish.,7: 339-337. 


\section{Stomach contents of the kuruma shrimp Marsupenaeus japonicus from the western Mediterranean Egyptian coast}

Barutot, R.A.; D’Incao, F. and Fonseca, D.B. (2011). Natural Diet of Neohelice granulata (Dana, 1851) (Crustacea, Varunidae) in Two Salt Marshes of the Estuarine Region of the Lagoa dos Patos Lagoon. Brazilian Archives of Biology and Technology, 54: 91-98.

Bello, G. and Pipitone, C. (2002). Predation on cephalopods by the giant red shrimp Aristaeomorpha foliacea. J. Mar. Biolog. Assoc. U.K., 82: 213-218.

El- Geziry, T.M.; Abd-Ella, R.G. and Maiyza, I. A. (2007). Bathymetric chart of Alexandria Eastern harbour. Egypt. J. Aquacult. Res., 33 (1): 1-21.

Hyslop, E.J. (1980). Stomach contents analysis - A review of methods and their application. J. Fish Biol., 17: 411-429.

Ishak, M.M.; Al-Sayes, A.A and Abdel Razek, F.A. (1980). Bionomics of Penaeus kerathurus transplanted into Lake Qaruo, Egypt. Aquacult., 21: 365-374.

Kapiris K.; Thessalou- Legaki, M.; Petrakis, G. and Conides, A. (2010). Ontogenetic shifts and temporal changes in the trophic patterns of the deep- sea red shrimp, Aristaeomorpha foliacea (Decapods: Aristeidae), in the Eastern Ionian Sea (Eastern Mediterranean). Mar. Ecol., 31: 341-354.

Lagardère J.P. (1972). Recherches sur l'alimentation des Crevettes de la Pente Continentale Marocaine. Tethys, 3: 655-675.

Lima, J.F., Garcia, J.S,Da Silva, T.C.(2014).Natural diet and feeding habits of a freshwater prawn (Macrobrachium carcinus: Crustacea, Decapoda) in the estuary of the Amazon River. ActaAmazonica, 44 (2):235-244.

Nouar A.; Kennouche H.; Ainoucheand N. and Cartes, J.E. (2011). Temporal changes in the diet of deep- water Penaeoidean shrimp (Parapenaeus longirostris and Aristeus antennatus) off Algeria (southwestern Mediterranean). Scientia Marina, 75(2): 279-288.

Rezende G. A, Pezzuto P. R., Dumonti L.C.,D'Incao F. (2012). Feeding habits of the deep-sea shrimp Aristaeopsisedwardsiana (Johnson 1867) (DECAPODA: ARISTEIDAE) on the Southeastern and Southern Brazilian coastPan-American Journal of Aquatic Sciences. 9(3):167-178.

Said, M.A. and Maiyza, I.A. (1987). Effect of the domestic sewage discharge on the hydrographic regime of the eastern harbour of Alexandria. Bull. Inst. Oceanogr. and Fish., B: 1-20.

Yassien, M .H. (1992). Biological studies on some shrimp species from the Gulf of Suez, Egypt. M.Sc. Thesis, Faculty of Science, Suez Canal University, Ismailia, Egypt.

Yassien M.; Bebars M. and Abdel-Razek F. (1993).Studies on the prawn fisheries in the Gulf of Suez, Egypt.Qatar University Scient. J.,13(2):358-363.

Yassien, M.H. (2004). Biology and fishery of the green tiger prawn penaeus semisulcatus De Haan 1850. In Bardawil Lagoon, Northern Sinai, Egypt. Bull. Nat. Inst. Oceanogr. and Fish., 30:1-22.

Wear R.G, Haddon M. (1987). Natural diet of the crab Ovalipes catharus (Crustacea: Portunidae) around central and northern New Zealand.Marine Ecology Progress Series, 35: 39-49.

Williams, M.J. (1981). Methods for analysis of natural diet in portunid crabs. (Crustacea: Decapoda: Portunidae). J. Exper. Mar. Biol. Ecol., 52: 103-113.

Zar, J.H. (1996). Biostatistical Analyses.Third Edition.Prentice Hall, New Jersey, USA. 121p. 


\title{
Nesreen K. Ibrahim et al.
}

\author{
محتويات المعدة للجمبرى كيريما "مارسوبنيس جابونيكس" من الساحل الغربى المصرى على البحر المتوسط

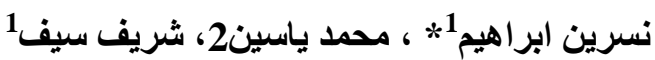

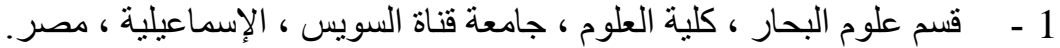

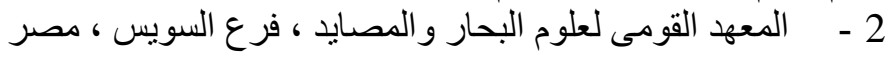 \\ *Email: Kadry1339@yahoo.com
}

\section{المستخلص}

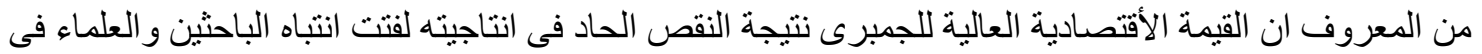

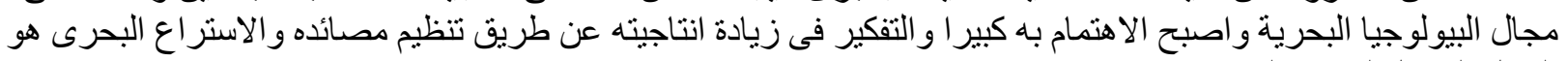
الشغل الثاغل لهو لاء الباحثيين.

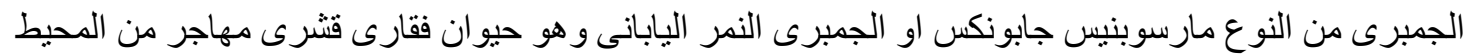

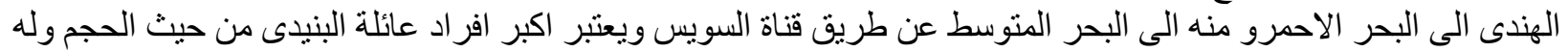

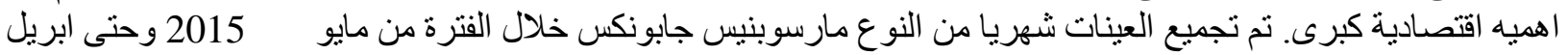

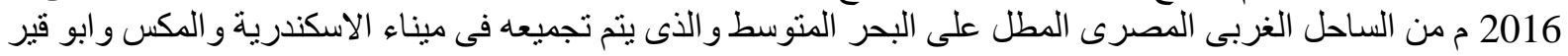
وذللك من مر اكب الجر العاملة على طول الساحل من السلو السلوم وحتى الاسكندرية.

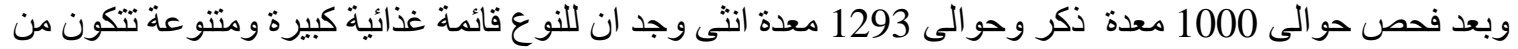

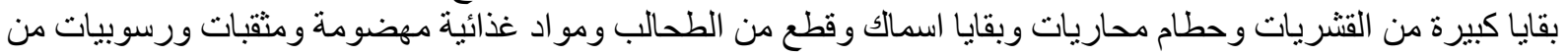

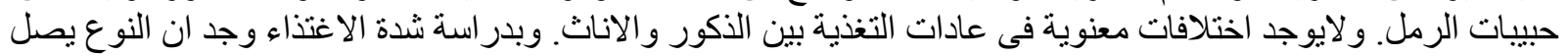

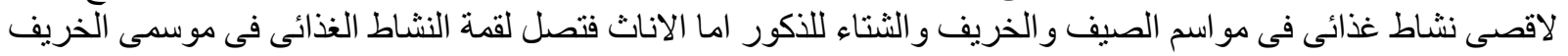

